\title{
CHANGE IN THE DISTRIBUTION OF THE INDIGENOUS GRASS POA LITOROSA ON SUB-ANTARCTIC MACQUARIE ISLAND FOLLOWING THE ERADICATION OF RABBITS
}

\author{
by Laura K. Williams, Chris Howard and Jenny Scott
}

(with five text-figures and two plates)

\begin{abstract}
Williams, L.K., Howard, C. \& Scott, J. 2016 (15:xii) Change in the distribution of the indigenous grass Poa litorosa on sub-Antarctic Macquarie Island following the eradication of rabbits. Papers and Proceedings of the Royal Society of Tasmania 150(2): 1-8. https://doi.org/10.26749/rstpp.150.2.1 ISSN 0080-4703. Agronomy and Soil Science, University of New England/ Australian Antarctic Division 203 Channel Highway, Kingston, Tas 7050 (LKW*), Tasmanian Parks and Wildlife Service, GPO Box 44 Hobart, Tasmania 7001, Australia (CH); Geography \& Environmental Studies, School of Land \& Food, University of Tasmania, Sandy Bay, Tasmania 7001, Australia (JS). *Author for correspondence. Email: laura.williams20@gmail.com
\end{abstract}

\begin{abstract}
The recent eradication of rabbits, rats and mice from Macquarie Island has resulted in unprecedented changes to the vegetation. One unforeseen outcome is the expansion in the known distribution of the indigenous grass, Poa litorosa (L.) which was known from only four restricted populations on Macquarie Island prior to 2014. An increase in abundance of P. litorosa was observed in 2014 and so we undertook surveys to document changes in the known distribution of the species and established fixed transects in the new and previously-recorded populations to monitor future changes. Monitoring of an exclosure and control plot over a 24-year period gave insights into past effects of rabbit grazing on the species. Our surveys documented a dramatic increase in the known distribution of the species. Existing populations have expanded and new populations have been recorded. Monitoring of the exclosure and control plot revealed suppression of $P$. litorosa plants in control plots in comparison to fenced plots during peak rabbit numbers, and so we attribute the population expansion to the recent eradication of rabbits and subsequent release of grazing pressure. This research contributes to the increasing bank of knowledge of changes occurring on Macquarie Island post-eradication and highlights the importance of monitoring to detect unforeseen changes.
\end{abstract}

Key Words: vegetation change, expansion, native species, grazing recovery, monitoring, Poa litorosa, Macquarie Island, rabbits, rodents.

\section{INTRODUCTION}

Macquarie Island, in the Australian sub-Antarctic, has recently been the focus of one of the largest integrated pest eradication programs to date, with all rats, rabbits and mice eradicated from the island in 2014 (Terauds et al. 2014). The European Rabbit (Oryctolagus cuniculus Linnaeus, 1758) had a catastrophic impact on the island's natural environment (Taylor 1955, Costin \& Moore 1960), causing local and landscape-scale damage. Tall herbfields and tussock grasslands were converted to short grazed lawns or bare ground by selective grazing (Copson \& Whinam 2001, Scott \& Kirkpatrick 2008, 2013, Bergstrom et al. 2009). The tall tussock and mega-herb vegetation provides important habitat for nesting seabirds and invertebrates and appears to reduce the incidence of land slippage and erosion (Scott unpubl. data, Bergstrom et al. 2009, Shaw et al. 2011, Springer 2011).

As a result of these impacts, the Macquarie Island Pest Eradication Project (MIPEP) was initiated by the Tasmanian Parks and Wildlife Service in 2007, and by July 2011 the rabbit population had been effectively reduced to zero. Extensive hunting and search efforts continued until complete eradication of rats, rabbits and mice was declared a success in 2014 (Terauds et al. 2014). Following rabbit eradication, changes to the vegetation were predicted to occur (Copson \& Whinam 2001) and, indeed, vegetation recovery and changing vegetation dynamics have already been observed (Scott \& Kirkpatrick 2013, Shaw et al.
2011, Whinam et al. 2014). One predicted outcome of the release of grazing pressure by rabbits is the expansion of some species and the reduction of others (Copson $\&$ Whinam 2001). A lack of historical data from the period prior to rabbit establishment (Whinam et al. 2014) together with ongoing climate change (Brothers \& Bone 2008, Adams 2009) make predictions about a new postgrazing equilibrium state of the vegetation uncertain. It is therefore essential to establish baseline data now, at the start of this new phase for Macquarie Island.

Poa litorosa Cheeseman, a tall tussock grass, was first recorded on Macquarie Island in 1984 and, until recently, was known from only four small populations (Bergstrom et al. 2006). Under heavy grazing, P. litorosa is difficult to distinguish from other grass species, particularly Festuca contracta Kirk (Bergstrom et al. 2006). Over the summer of $2013 / 14$, it was noted in several new locations. This paper describes the distribution, abundance and apparent spread of $P$. litorosa on Macquarie Island in the absence of rabbit grazing and provides baseline data for measurement of future change in its distribution and abundance. In addition, we present 24 years of monitoring data on fixed transects in an exclosure plot and adjacent control plot which show the effects of past rabbit grazing on $P$. litorosa.

\section{Study site}

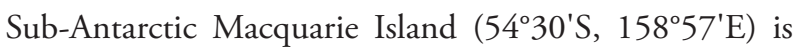
located in the Southern Ocean approximately $1500 \mathrm{~km}$ 
southeast of Tasmania. The climate is cool, wet and windy. Mean temperatures of the coolest and warmest months range between $3^{\circ} \mathrm{C}$ and $7^{\circ} \mathrm{C}$, mean annual precipitation is around $950 \mathrm{~mm}$ and winds are predominantly strong and west to northwesterly (Pendlebury \& Barnes-Keoghan 2007). Analysis of changing climate patterns indicates that precipitation and wind speeds are increasing, consistent with an increase in cyclonic weather events. At the same time an increase in atmospheric dryness, along with the increase in wind speeds, may be contributing to drying of the island's surface (Adams 2009).

The flora of Macquarie Island is dominated by grasses, herbs and bryophytes with trees and shrubs completely absent (Selkirk et al. 1990). Forty-two indigenous and seven exotic vascular species have been recorded (de Salas \& Baker 2015). The island is considered high conservation value due to its abundance of wildlife and unique geology. It is a nature reserve, UNESCO biosphere reserve and World Heritage area (Carmichael 2007, de Villiers et al. 2006).

\section{Poa litorosa}

Poa litorosa is a tall, wiry tussock abundant on the cold temperate New Zealand shelf islands of the Auckland Island group, Campbell Island and Antipodes (Du Puy et al. 1993, Frenot et al. 2005). On Campbell Island P. litorosa grows most vigorously on sites with enhanced fertility such as coastal areas, swamp flushes and near wildlife colonies, while in upland areas plants are commonly smaller (Meurk et al. 1994). P. litorosa is also present on Macquarie Island, the only sub-Antarctic island on which it is found (Bergstrom et al. 2006), and patterns of growth appear similar to those on Campbell Island. The species was first observed on Macquarie Island by G. Copson in 1983 (P. Turner pers. comm.) and recorded by Seppelt et al. in 1984. Between 1983 and 1985 four populations of P. litorosa were documented, the largest in the north at Handspike Point near sea-level and three small higher-altitude populations at Caroline Cove Amphitheatre, Caroline Creek and Hill 291 on the southern end of the island (Bergstrom et al. 2006) (fig. 1). In the early 1950s B.W. Taylor identified a population of large tussocks at Handspike Point as Festuca erecta d'Urv. (contracta) which was likely to have been a misidentification of P. litorosa (Taylor 1955, Bergstrom et al. 2006). Between the 1980s and 2003 various observations were made of the four populations by Bergstrom et al. (2006).

\section{METHODS}

\section{Documentation of Poa litorosa distribution}

In February 2014, we observed that $P$. litorosa in areas immediately adjacent to the rabbit grazing exclosure at the Caroline Cove Amphitheatre exhibited a general increase in size, vigour and extent. A thorough distribution survey could not be completed at the time due to inclement weather. During periods of more favourable weather and so improved visibility during March-June 2014, thorough searches were undertaken. Walking line transects were made 15-20 m apart where topography allowed, around the three known southern populations of P. litoros a and in all short grassland communities south of latitude $54^{\circ} 44^{\prime} \mathrm{S}$ (fig. 1). The location of any clumps of $P$. litorosa were recorded with a hand-held GPS unit and the number of plants and presence/absence of seed heads noted. Data were uploaded to the Natural Values Atlas database managed by the Department of Primary Industries, Parks, Water and the Environment, Tasmania.

In March 2014 the Handspike Point P. litorosa population was inspected and a brief visual comparison was made with the 2006 map of its extent in Bergstrom et al. (2006). Several photos were re-taken from photomonitoring points set up at the southwest edge of the population in February 2009 (J. Scott), 1-2 years before rabbit eradication.

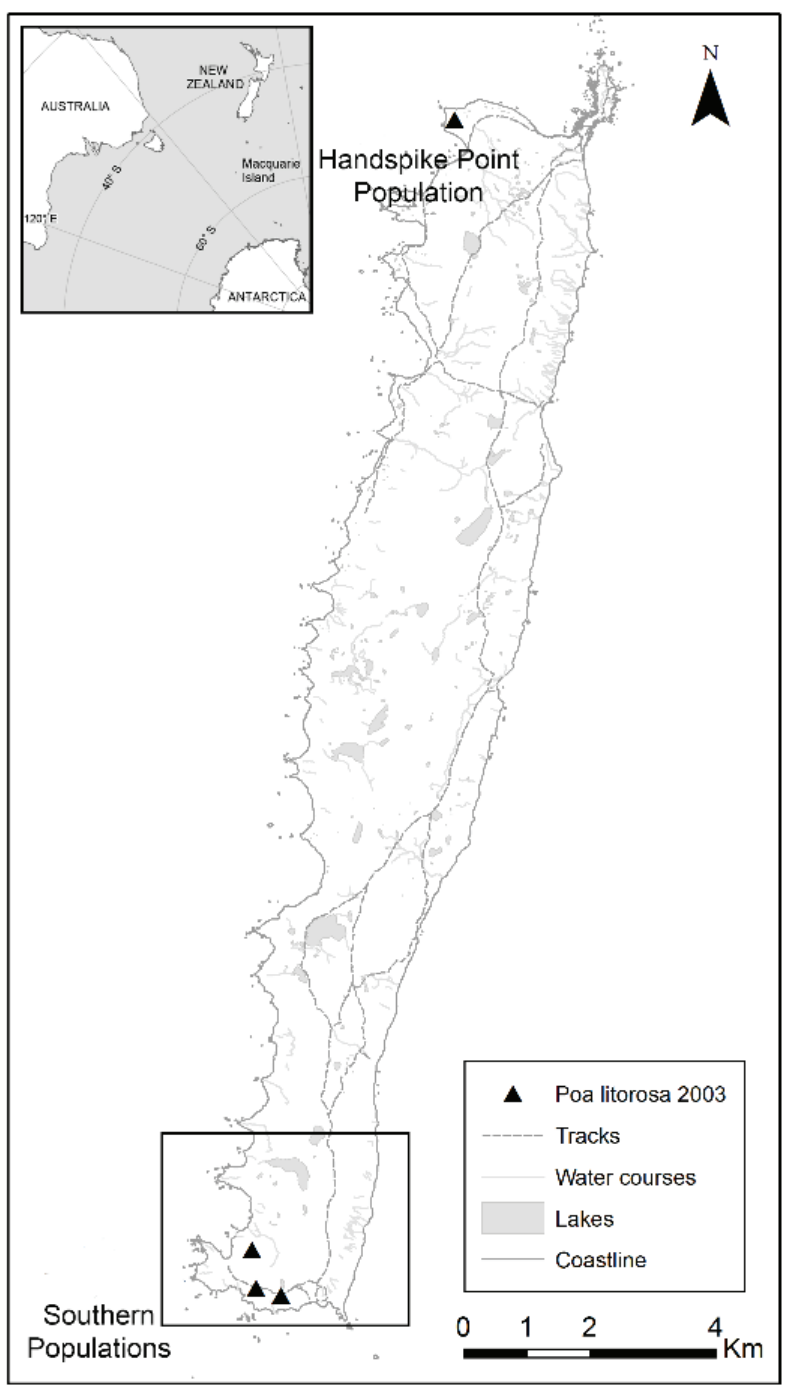

FIG. 1 - Extent of the area in the south of Macquarie Island searched for the presence of Poa litorosa (indicated by black box), south of latitude $54^{\circ} 44^{\prime}$ S. Black triangles indicate Poa litorosa populations recorded prior to 2014. 


\section{Establishment of fixed transects for future monitoring and quantification of foliage cover}

During January-June 2014 fixed transects were established at Caroline Creek, Carrick Bay and two sites within the Caroline Cove Amphitheatre population (Caroline Cove Amphitheatre 1 and 2) to enable monitoring of future changes in distribution and abundance of $P$. litorosa. A line transect method was used, as presented in Cloud (2009). The centre of the P. litorosa population was marked with a small wooden peg and eight $30 \mathrm{~m}$-long transects run out from the centre point at $0,45,90,135,180,225,270$ and $315^{\circ}$ (fig. 2). The distances at which $P$. litorosa intersected the transect was recorded (i.e., $5-8 \mathrm{~cm}$ ). A photograph looking down the transect away from the centre peg was taken. Elevation, aspect, latitude and longitude were recorded with a handheld GPS.

\section{Documentation of grazing pressure along fixed transects, Caroline Cove Amphitheatre population}

In 1990 a $5 \times 5 \mathrm{~m}$ fenced exclosure and an adjacent $5 \times$ $5 \mathrm{~m}$ control plot were erected around part of the Caroline Cove Amphitheatre population to protect the plants from rabbit grazing (Bergstrom et al. 2006). Over the next 24 years to 2015, line intercept (percentage cover) and plant height data were collected at irregular intervals (1990, 1991, 1995, 2003, 2015) along four fixed 5-m transects, two each in the exclosure and control plots. The distances at which $P$. litorosa intersected the transect and the maximum height of each clump along the transect was recorded and the percentage of each clump which showed signs of rabbit damage (grazed shoots) was visually estimated. Fixed-point photographs were taken each time the measurements were made.

\section{Data analysis}

GPS locations of $P$. litorosa populations were imported into ESRI ${ }^{\oplus}$ ArcMap $^{T M} 10.0$ and expressed as UTM grid coordinates based on the WGS 1984 Datum. The mean percentage cover of $P$. litorosa at each site was determined by calculating the percentage of the transect length that was intercepted by $P$. litorosa and averaging across all eight transects. Statistical analyses were carried out using $\mathrm{R}$ version 3.1.1. Results were analysed using analysis of variance (ANOVA). Variances were checked by plotting residual versus fitted values to confirm the homogeneity of the data and normality was checked by quantile-quantile comparison plots. Significant means were separated using Tukey's highest significant difference test.

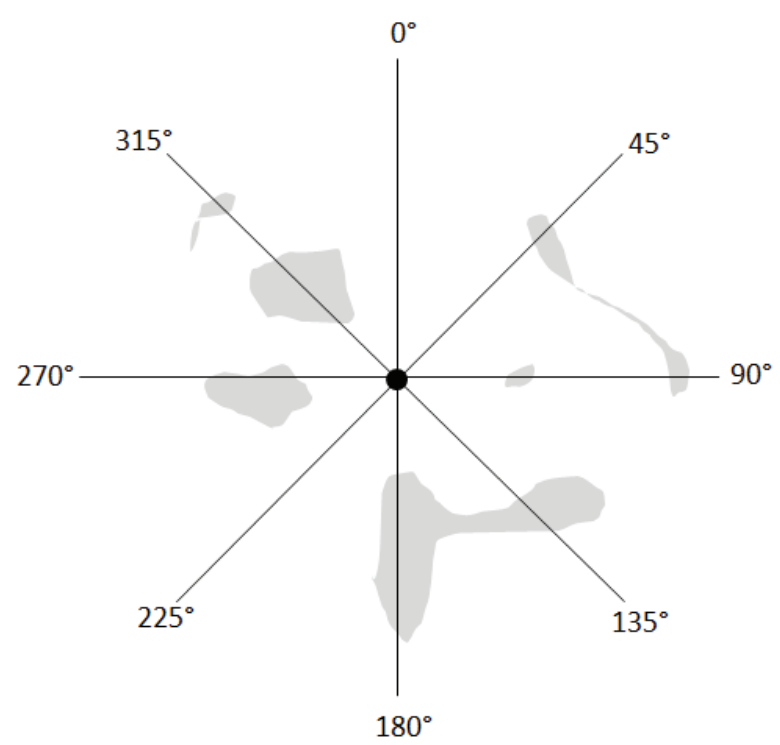

FIG. 2 - Schematic diagram of method used to survey Poa litorosa cover, showing angles of line transects from the centre point of the population. Grey areas depict $P$. litorosa.

\section{RESULTS AND DISCUSSION}

\section{Poa litorosa distribution (fig. 3)}

In February 2014, it was noted that the growth and abundance of $P$. litorosa had increased around the exclosure at the Caroline Creek Amphitheatre population, and plants were larger and of a size not seen since prior to the increase in the rabbit population of the 1990s (J. Scott unpubl. data). This led to further surveys of the distribution of P. litorosa which identified an increase in the known distribution of $P$. litorosa around the three previously documented southern

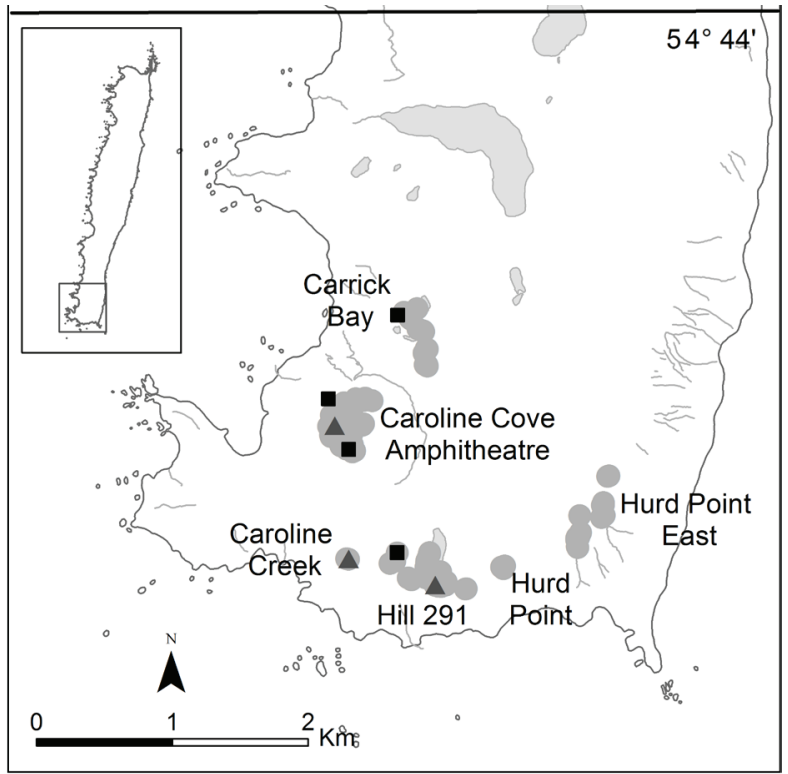

FIG. 3 - Distribution of Poa litorosa on Macquarie Island in 2003 (dark grey triangles) and 2014 (light grey circles). Monitoring sites established in 2014 are indicated by black squares. 
populations and the discovery of three additional, previously unrecorded, populations.

We observed an expansion in the known distribution of the three previously documented populations of P. litorosa in the south of the island, Caroline Cove Amphitheatre, Caroline Creek and Hill 291. The Caroline Cove Amphitheatre population was first recorded in 1983 by G. Copson, and in 1991 consisted of scattered clumps within a $2500 \mathrm{~m}^{2}$ area at $160 \mathrm{~m}$ a.s.l. with occasional clumps up to $150 \mathrm{~m}$ to the south (Bergstrom et al. 2006). In 2003 the population consisted of numerous clumps within a $10 \mathrm{~m}$ radius of the enclosure, scattered clumps to $20 \mathrm{~m}$ and occasional clumps between $20-38 \mathrm{~m}$, but this was the minimum extent of the population as bad weather and grazing damage meant it was difficult to distinguish P. litorosa plants (Bergstrom et al. 2006). The authors suggested the population was increasing but could not make a firm assessment of the degree of change. The population had never been observed flowering (Bergstrom et al. 2006). Our survey in 2014 documented P. litorosa plants at a distance of $50 \mathrm{~m}$ away from the exclosure. Many hundreds of individuals and small clumps were detected throughout the whole amphitheatre, to a distance of around $300 \mathrm{~m}$ from the exclosures and extending over an area of around $22000 \mathrm{~m}^{2}$. Several plants were observed flowering.

The Caroline Creek population was first recorded in November 1983 by G. Copson and consisted of two small tussocks at approximately $180 \mathrm{~m}$ a.s.l. In August 1990 the population consisted of four small tussocks, ranging from $0.5 \times 0.5 \mathrm{~m}$ to $0.3 \times 0.7 \mathrm{~m}$ in diameter, growing $5-10 \mathrm{~m}$ apart along the edge of the creek, but by February 2003 the population had been reduced to one small, rabbit-grazed patch $0.1-0.15 \mathrm{~m}$ in diameter (Bergstrom et al. 2006). Our survey in 2014 documented around 60 plants covering an area of around $300 \mathrm{~m}^{2}$. None was observed flowering.

The Hill 291 population was initially documented by G. Copson in September 1984 and consisted of a single clump along a ridgeline in feldmark/herbfield at $220 \mathrm{~m}$ a.s.l. near Hill 291. Between 1984 and 2003 this population was not investigated further (Bergstrom et al. 2006). Our surveys in 2014 documented an increase in the known distribution of this population around Hill 291 and a scattering of $P$. litorosa tussocks halfway up the eastern and western banks surrounding Lake Ainsworth which had not been previously recorded. The population consisted of around 200 plants spanning an area of around $18000 \mathrm{~m}^{2}$ with clumps up to $30 \mathrm{~m}^{2}$ in size. Plants had a maximum height of 40-50 cm, although most were much smaller, and no plants were observed flowering. Some of these tussocks were seen in 2009 on the high western banks of Lake Ainsworth as part of a photo-monitoring point, but it was concluded at the time that it was $P$. foliosa regrowth without closer observation (J. Scott unpubl. data).

We documented little change in the known distribution and abundance of $P$. litorosa at Handspike Point. This population was first recorded in the 1950s (Taylor 1955) when it was documented incorrectly as Festuca erecta (now contracta) and described as a dozen or so very scattered tussocks, $0.8-0.9 \mathrm{~m}$ tall $\times 0.9 \mathrm{~m}$ wide. In 2003, the population was scattered over a $4800 \mathrm{~m}^{2}$ area at $10-15 \mathrm{~m}$ a.s.l., and was characterised by large, tall tussocks $(1.2 \mathrm{~m}$ tall $\times 1.0 \mathrm{~m}$ wide $)$, many of which were flowering abundantly (Bergstrom et al. 2006). When visually inspected in February 2014, distribution boundaries mapped in 2003 by Bergstrom et al. (2006) did not appear to have changed significantly and photo retakes taken at several photo-monitoring points set up in 2009 showed little change between 2009 and 2014 at the southern boundary of the site. The 2009 photo (pl.1a) indicates signs of light grazing, while the 2014 photo (pl. 1b) shows slightly denser and higher tussock growth. Some plants were observed flowering. In 2014 many of the tussocks seemed to have expanded, filling inter-tussock spaces evident in 2009, as well as being larger and denser.

Our surveys also detected three previously unrecorded populations of P. litorosa at Carrick Bay, Hurd Point and Hurd Point East in the south of the island. The Carrick Bay population was detected en route to Cape Star in a small drainage line on the lower plateau immediately east of Cape Star at an elevation of 200-280 m a.s.l. This population consisted of many hundreds of scattered individuals and small clumps across an area of $44900 \mathrm{~m}^{2}$, with some

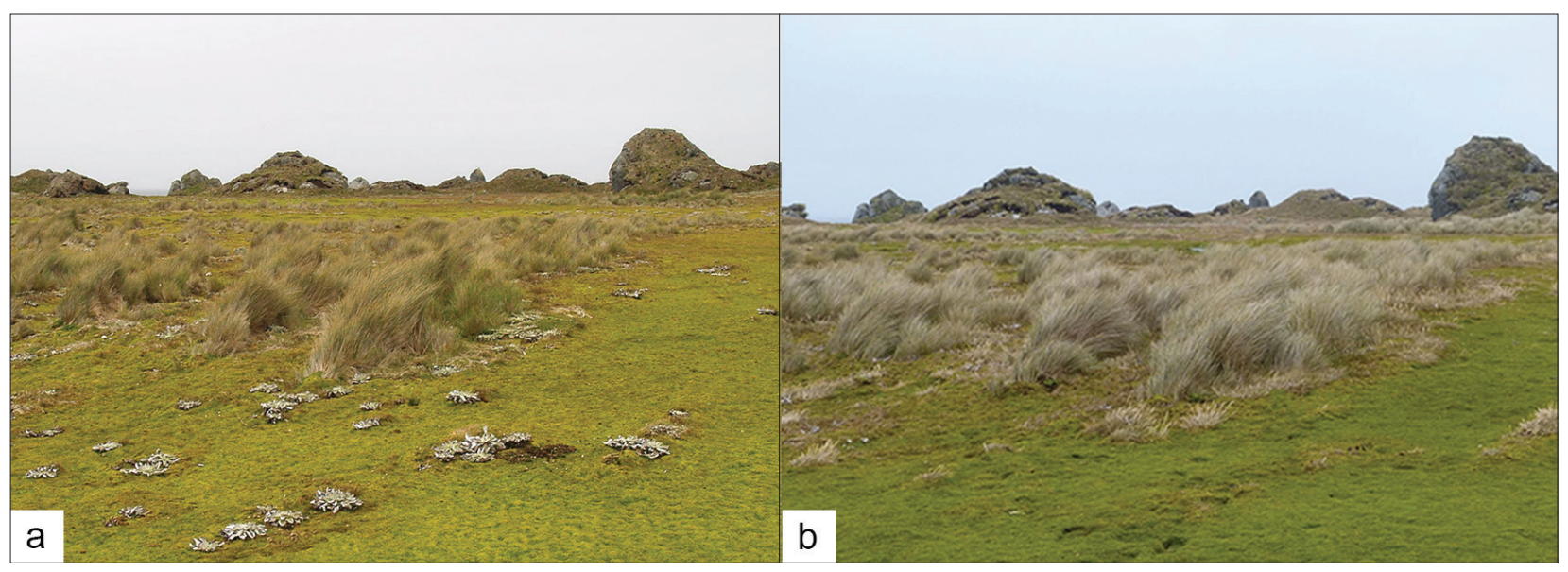

PLATE 1 - Poa litorosa at Handspike Point in 2009 (a) and P. litorosa at Handspike Point in 2014 (b), taken from the same photopoint. 

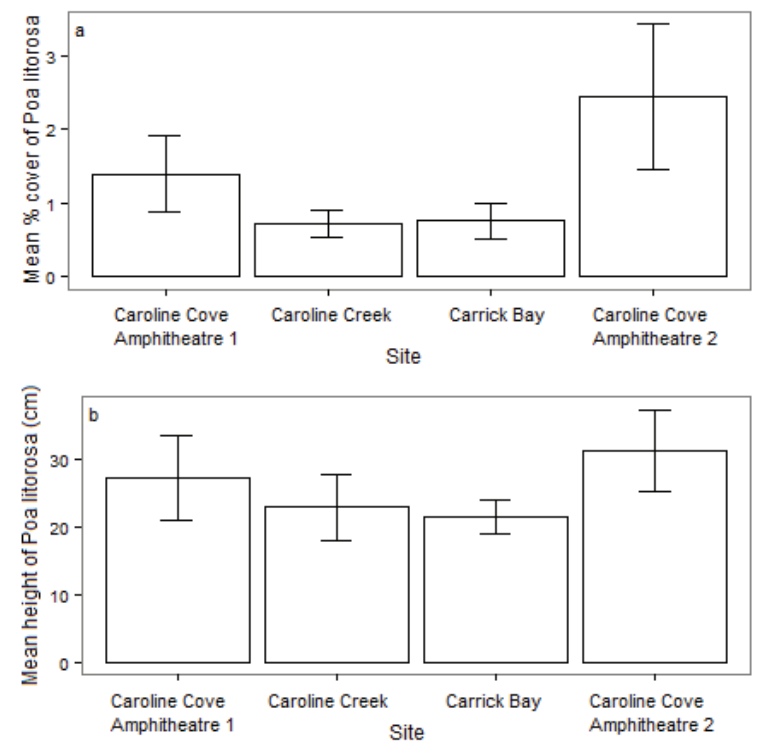

FIG. 4 -Mean percentage cover of Poa litorosa at four sites on Macquarie Island in 2014, $\mathrm{n}=8$ (a); and mean height of $P$. litorosa at four sites on Macquarie Island in 2014 (b), measured along $8 \times 30 \mathrm{~m}$ line transects at each site. Error bars represent $95 \%$ confidence intervals.
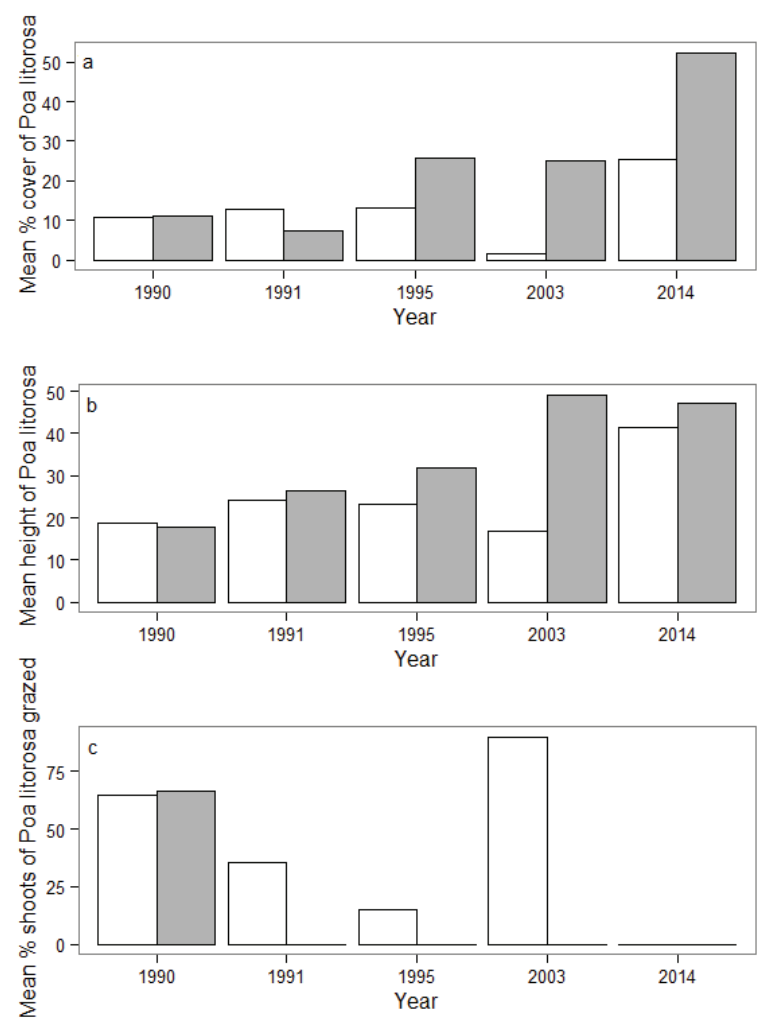

FIG. 5 - Mean percentage cover (a); height (b) and percentage of shoots grazed (c) of Poa litorosa in control (unfilled bars) and exclosure (filled bars) plots at Caroline Cove Amphitheatre over a 24-year period, measured along 4 × 5-m fixed line transects. clumps up to $40 \mathrm{~m}^{2}$. Plants were around $20-30 \mathrm{~cm}$ in height and some were observed flowering. The Hurd Point population consists of around 270 plants growing along the top of the escarpment below the ridgeline at an elevation of 230-260 m with a southeasterly aspect. Plants were around $20-25 \mathrm{~cm}$ in height. None was observed flowering. The Hurd Point East population consisted of five plants growing at the top of the south-facing escarpment at an elevation of $240 \mathrm{~m}$. Plants were small in size and none was observed flowering. No new populations were documented around the Handspike population or opportunistically visited locations in the north of the island.

\section{Baseline data collection for future monitoring}

Data on the abundance and distribution of P. litorosa was collected along fixed transects at four sites (Caroline Cove Amphitheatre 1 and 2, Caroline Creek, Carrick Bay). These data describe the proportion of each of eight transects per site intersected by $P$. litoros $a$ and the height of each clump of $P$. litorosa intersecting the transect. This information provides a detailed baseline dataset on which future monitoring of P. litorosa can be based and is available from the Natural Values Atlas database (Department of Primary Industries, Parks, Water and the Environment, Tasmania) and will be available at the Australian Antarctic Data Centre. These data were used to determine the mean percentage cover of P. litorosa at each site and ranged from 0.7 to $2.4 \%$ cover (fig. 4). The mean height of P. litorosa plants was around $25 \mathrm{~cm}$ at each of these four sites (fig. 4).

\section{Changes in the Caroline Cove Amphitheatre exclosure and control plot over time in response to grazing pressure}

There were no statistical differences in the mean percentage cover, height and percentage of shoots grazed between the exclosure and control plot at each time period $(P \geq$ 0.05 ). This was due to a low number of replicates and high variability in the data as this experiment was established quickly and $a d$-hoc in 1990 by scientists concerned about the survivorship of P. litorosa at the peak of rabbit grazing. However, the data still give important insights into the impacts of rabbit grazing on P. litorosa. When the plots were first established, there was little difference in the heights of $P$. litorosa shoots, the abundance of $P$. litorosa along the transects, and the percentage of $P$. litorosa shoots which were grazed (fig. 5), between the exclosure and control plot. Within the exclosure the mean maximum height of ungrazed $P$. litorosa shoots increased over the 13-year period until 2003, with a large increase between 1995 and 2003, and showed a slight decrease 11 years later in 2014 (possibly an artefact of a different researcher doing the later measurements). In the control plot the mean maximum height of shoots changed little until 2003, indicating a regular overall pattern of grazing of the species with shoots being eaten down to $12-15 \mathrm{~cm}$ and never reaching above $24 \mathrm{~cm}$ (fig. 5). The increase in height of $P$. litorosa in the control plot during the first six months, between the initial 
measurement in August 1990 and the second measurement six months later in February 1991, is likely to represent spring and summer growth.

Percentage cover of the transect lines by $P$. litorosa increased within the exclosure plot over the 24-year period, although there was some fluctuation within this period. Percentage cover increased for the first five years, remained stable for the next eight years and had increased greatly by 2014 . The mean percentage cover of $P$. litorosa in the control plot remained relatively stable for the first five years to 1995 and then decreased to 2003, exhibiting an inverse pattern to the changes in cover of P. litorosa in the exclosure plot, then increased greatly by 2014 . The mean percentage of $P$. litorosa shoots that were grazed within the exclosure plot declined to zero in the first six months of the study period, indicating the success of the fencing at excluding rabbits. Within the control plot, the mean percentage of $P$. litorosa shoots that were grazed declined over the first five years, and then increased over the next eight years until 2003. This is likely to reflect fluctuations in rabbit numbers in the Caroline Cove Amphitheatre, with heavier grazing pressure during the first, second and fourth measurement periods $(1990,1991,2003)$ than during the third (1995). This follows the general trend in rabbit numbers for the island as a whole over this period (Terauds et al. 2014). No grazing was observed in 2014 as grazing pressure had ceased several years before this measurement.
The photo-point photographs of the exclosure and control plots over the 24 years confirm the trends discussed above (pl. 2). There was an increase in growth and extent of $P$. litorosa in a control plot over the first five years to February 1995, compared to the previous measurement in February 1991. A comparison of plate 2a, b and c shows a decrease in growth and extent of P. litorosa in the control plot over the 12.5 years to February 2003 and the steady increase in height of P. litorosa in the exclosure over the 12.5 years. By February 2003 the exclosure plants had started to develop into distinct small tussocks (pl. 2c), away from the uneven discontinuous turf habit displayed during previous measurements and still evident in the control (pl. 2a, b). By 2014, growth and extent of P. litorosa had increased markedly in both exclosure and control (pl. 2d).

\section{CONCLUSIONS}

A substantial increase in the recorded distribution of $P$. litorosa has been seen between 2003 and 2014 and we attribute this to a release of grazing pressure following the eradication of rabbits. The three previously known southern populations were first detected following the postmyxomatosis decline in rabbit numbers in the early 1980 s when grazing pressure was reduced (Terauds et al. 2014). Indeed, P. litorosa has been found to decline in the presence

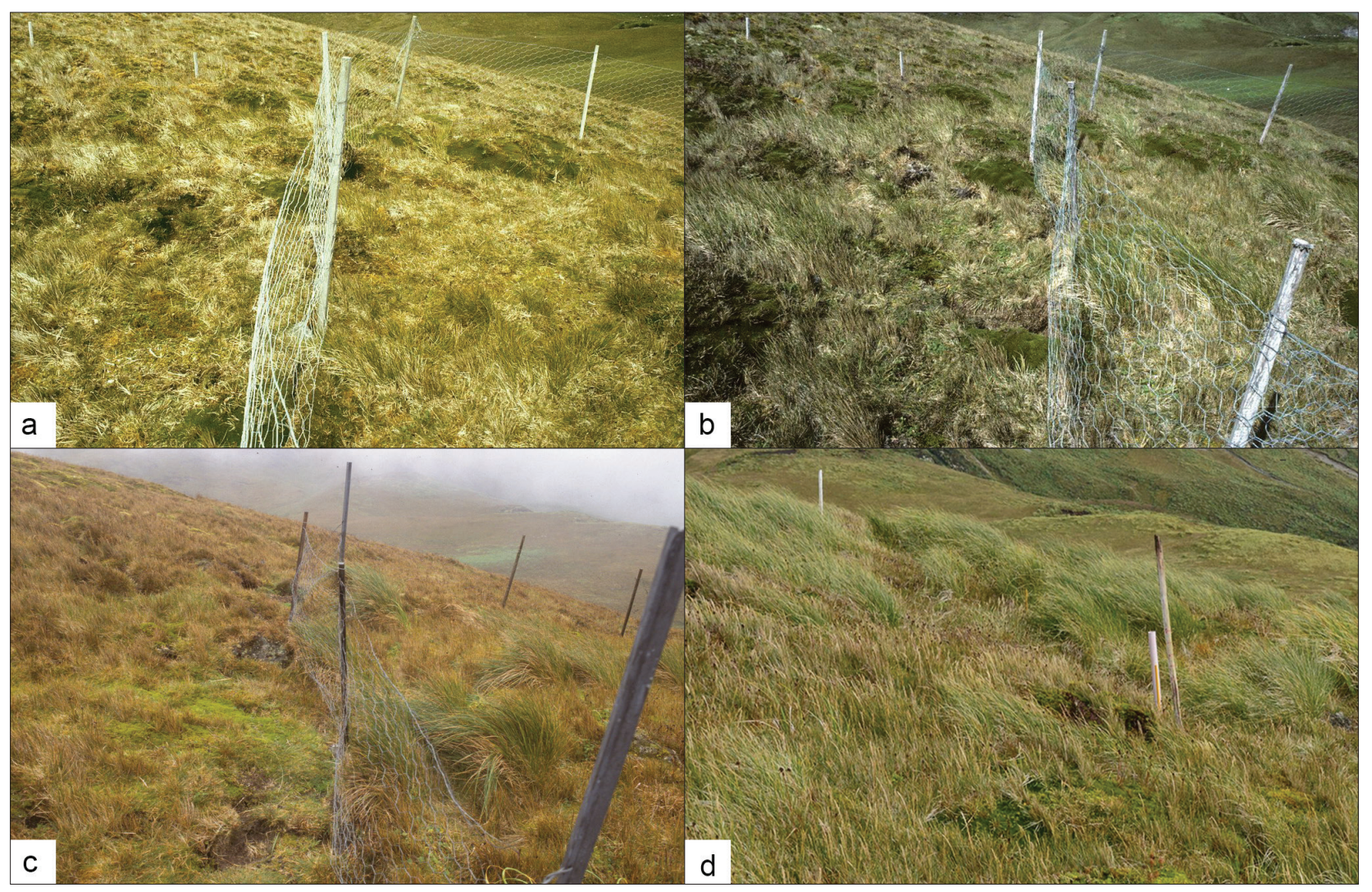

PLATE 2- Changes in the abundance and height of Poa litorosa between 1991 (a), 1995 (b), 2003 (c) and 2014 (d) in a control plot (left side of fence line) and in an exclosure plot (right side of fence line). Note fence had been removed by 2014 as rabbits had been eradicated, although corner posts remain for reference. 
of grazing and increase when grazing ceased on several of the New Zealand shelf islands (Dilks \& Wilson 1979, Rudge \& Campbell 1977, Taylor 1968, UNESCO 1966). When grazed, P. litorosa and $F$. contracta are difficult to tell apart, thus these populations may have been established for some time but were not detected previously due to grazing impacts (Bergstrom et al. 2006). For the same reasons, further populations were not detected during this time. Following the eradication of rabbits, the grazing pressure on the vegetation has been completely lifted, allowing plants to grow unrestricted. Given the substantial size of many of the P. litorosa plants, it is likely these populations have been present for a long time but have been maintained at undetectable levels by rabbit grazing. The effects of grazing on P. litorosa are illustrated in plate 2 .

Although we observed dramatic changes in the P. litorosa populations in the south of the island, the Handspike Point population differed little between 2003 and 2014. This site has a very different environment to the southern sites, including lower elevation, higher exposure and waterlogged soil. The Handspike Point population, although grazed, appears not to have been as heavily grazed as the southern population (Bergstrom et al. 2006) and so has probably been less affected by the release of grazing pressure. Further observations at the described sites will enable future changes in populations of $P$. litorosa to be documented.

\section{ACKNOWLEDGEMENTS}

The fieldwork for this project was undertaken while the authors were on Macquarie Island during the 2013-14 summer field season, and completed by $\mathrm{CH}$ over the 2014 winter. L.W. was on Macquarie Island with Australian Science Project 4158, and J.S. with Non-Science Project 3351. Fieldwork measurements on the Caroline Cove Amphitheatre exclosure and control plot between 1990 and 2009 were undertaken by J.S. with Antarctic Science Project 2317. Access to Macquarie Island was provided by the Tasmanian Parks and Wildlife Service. Logistical support was provided by the Australian Antarctic Division.

\section{REFERENCES}

Adams, N. 2009: Climate trends at Macquarie Island and expectations of future climate change in the sub-Antarctic. Papers and Proceedings of the Royal Society of Tasmania 143: $1-8$.

Bergstrom, D.M., Lucieer, A., Kiefer, K., Wasley, J., Belbin, L., Pedersen, T.K., \& Chown, S.L. 2009: Indirect effects of invasive species removal devastate World Heritage Island. Journal of Applied Ecology 46: 73-81. doi: 10.1111/j.13652664.2008.01601.x

Bergstrom, D.M., Turner, P.A.M., Scott, J., Copson, G. \& Shaw, J. 2006: Restricted plant species on sub-Antarctic Macquarie and Heard Islands. Polar Biology 29: 532-539. doi: 10.1007/s00300-005-0085-2

Brothers, N. \& Bone, C. 2008: The response of burrow-nesting petrels and other vulnerable bird species to vertebrate pest management and climate change on sub-Antarctic
Macquarie Island. Papers and Proceedings of the Royal Society of Tasmania 142: 123-148.

Carmichael, N. 2007: Macquarie Island, its conservation and management. Papers and Proceedings of the Royal Society of Tasmania 141: 11-17.

Cloud, A. (ed.) 2009: Australian Soil and Land Survey Field Handbook. CSIRO Publishing, Collingswood, Victoria: $264 \mathrm{pp}$.

Copson, G. \& Whinam, J. 2001: Review of ecological restoration programme on subantarctic Macquarie Island: Pest management progress and future directions. Ecological Management and Restoration 2: 129-138. doi: 10.1046/j.1442-8903.2001.00076.x

Costin, A.B. \& Moore, D.M. 1960: The effects of rabbit grazing on the grasslands of Macquarie Island. Journal of Ecology 48: 729-732. doi: 10.2307/2257346

de Salas, M. \& Baker, M. 2015: A Census of the Vascular Plants of Tasmania and Index to the Student's Flora of Tasmania and Flora of Tasmania Online.Tasmanian Herbarium, Tasmanian Museum and Art Gallery, Hobart, http://www. tmag.tas.gov.au/collections_and_research/tasmanian_ herbarium/tasmanian_herbarium_publications (accessed 1 October 2015).

de Villiers, M.S., Cooper, J., Carmichael, N., Glass, J.P., Liddle, G.M., McIvor, E., Micol, T. \& Roberts, A. 2006: Conservation management at Southern Ocean islands: towards the development of best-practice guidelines. Polarforschung 75: 113-131. doi: 10.1007/s003000050423

Dilks, P. \& Wilson, P. 1979: Feral sheep and cattle and royal albatrosses on Campbell Island; populations trends and habitat changes. New Zealand Journal of Zoology $\mathbf{6}$ : 127-139.

Du Puy, D.J., Telford, I.R.H. \& Edgar, E. (eds) 1993: Poaceae., Flora of Australia, Oceanic Islands. Australian Government Publishing Service, Canberra: 406 pp.

Frenot, Y., Chown, S.L., Whinam, J., Selkirk, P.M., Convey, P., Skotnicki, M. \& Bergstrom, D.M. 2005: Biological invasions in the Antarctic: extent, impacts and implications. Biological Reviews 80: 4-72. doi: 10.1017/ S1464793104006542

Meurk, C., Foggo, M. \& Wilson, J. 1994: The vegetation of subantarctic Campbell Island. New Zealand Journal of Ecology 18: 123-168.

Pendlebury, S. \& Barnes-Keoghan, I.P. 2007: Climate and climate change in the sub-Antarctic. Papers and Proceedings of the Royal Society of Tasmania 141: 67-81.

Rudge, M. \& Campbell, D. 1977: The history and present status of goats on the Auckland Islands (New Zealand subantarctic) in relation to vegetation changes induced by man. New Zealand Journal of Botany 15: 221-253.

Scott, J.J. \& Kirkpatrick, J.B. 2008: Rabbits, landslips and vegetation change on the coastal slopes of subantarctic Macquarie Island, 1980-2007: Implications for management. Polar Biology 31: 409-419. doi: 10.1007/ s00300-007-0367-y

Scott, J.J. \& Kirkpatrick, J.B. 2013: Changes in the cover of plant species associated with climate change and grazing pressure on the Macquarie Island coastal slopes, 1980-2009. Polar Biology 36: 127-136. doi: 10.1007/s00300-012-1243-y

Selkirk, P., Seppelt, R. \& Selkirk, D. 1990: Subantarctic Macquarie Island: Environment and Biology. Cambridge University Press, Cambridge: 285 pp.

Seppelt, R., Copson, G. \& Brown, M. 1984: Vascular flora and vegetation of Macquarie Island. Tasmanian Naturalist 78: 7-12.

Shaw, J.D., Terauds, A. \& Bergstrom, D.M. 2011: Rapid commencement of ecosystem recovery following aerial baiting on sub-Antarctic Macquarie Island. Ecological Management \& Restoration 12: 241-244. doi: 10.1111/j.1442-8903.2011.00611.x 
Springer, K. 2011: Planning processes for eradication of multiple pest species on Macquarie Island - an Australian case study. In: Veitch, C.R., Clout, M.N. \& Towns, D.R. (eds), Island Invasives: Eradication and Management. International Union for Conservation of Nature, Gland: 228-232.

Taylor, B.W. 1955: The flora, vegetation and soils of Macquarie Island. Botany, Hobart: 192 pp.

Taylor, R. 1968: Introduced mammals and islands: Priorities for conservation and research. Proceedings of the New Zealand Ecological Society 15: 61-67.

Terauds, A., Doube, J., McKinlay, J. \& Springer, K. 2014: Using long-term population trends of an invasive herbivore to quantify the impact of management actions in the sub-Antarctic. Polar Biology 37: 833-843. doi: 10.1007/ s00300-014-1485-y
UNESCO. 1966. Towards a new relationship of man and nature in temperate lands. Part II of the 10th Technical Meeting of the International Union of the Conservation of Nature, Lucerne. I.U.C.N.

Whinam, J., Fitzgerald, N., Visoiu, M. \& Copson, G. 2014: Thirty years of vegetation dynamics in response to a fluctuating rabbit population on sub-Antarctic Macquarie Island. Ecological Management \& Restoration 15: 41-51. doi: 10.1111/emr.12076

(accepted 5 July 2016) 